steel was readily determined, which had been difficult to be determined by the conventional method. The molar absorbancy was $5.00 \times 10^{4}$, which showed higher sensitivity than the determination in an aqueous phase by the same reagent. The proposed method was more practical than the pyridine method with cyclohexane extraction.

(Received Dec. 12, 1969)

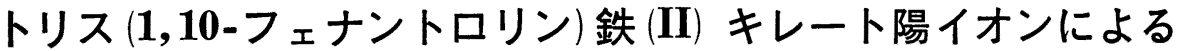

\section{クロム $(\mathbf{V I})$ の溶媒抽出吸光光度定量法*}

\author{
山本勇麓，熊丸尚宏，林 康久，木村繁和，深水 清**
}

(1970 年 1 月 10 日受理)

\begin{abstract}
溶媒抽出に基べくクロム (VI) の新しい吸光光度法を開発した．適量のトリス $(1,10-$ フェナントロリ ン)鉄(II) キレート陽イオンが水相に存在するとクロム (VI) が選択的にニトロベンゼンに抽出される ととを見いだした． pH 3〜4 の範囲で金属キレート濃度をクロム(VI)の50倍過剩に保てば一定の 抽出が得られた。水相中に存在していたクロム (VI) 濃度が $62.5 \mu \mathrm{g} / 25 \mathrm{ml}$ 以下の範囲で, 抽出相の $\lambda_{\max }(516 \mathrm{~m} \mu)$ の吸光度とクロム濃度との間には直線性が成立した。抽出種は微酸性におけるクロム 酸イオンの平衡定数から考元て $\left[\mathrm{Fe}(\mathrm{phen})_{3}{ }^{2+}\right] \cdot\left[\mathrm{HCrO}_{4}-\right]_{2}$ と推定された. 抽出相の呈色強度は 24 時 間の放置でもほとんど一定であった. $2.08 \mu \mathrm{g} / \mathrm{ml}$ クロムの 11 試料についての標準偏差は, 平均吸光 度 0.4001 に対して $0.52 \%$ であった。多量の鉄（III）はかなりの負誤差を与光るので，メチルイソブ チルケトンーiso 酶酸アミル混合溶媒による抽出で鉄 (III) を除去する方法を検討した.

クロム（III）の酸化には過酸化水素水を用いた．純鉄をマトリックスとしたクロム（III）から得た 検量線はやや低いクロムの回収率を示すが，この方法を鉄鋼中のクロムの分析に応用してよい結果を得 た。
\end{abstract}

\section{1 緒 言}

微量のクロムの吸光光度定量法としてはジフェニルカ ルバジト法1がよく用いられており，JIS法にも採用され ている.そのほかメチルバイオレット2)，トリフェニル スルホニウム3) やテトラフェニルホスホニウム4)による クロム酸陰イオンの抽出比色法およびコバルト-EDTA と $\mathrm{Cr}_{2} \mathrm{O}_{7}{ }^{2-}$ との複雑な呈色反応を利用するクロムの定 量法5) も報告されている. 著者らは赫色のトリス $(1,10$ フェナントロリン)鉄(II) キレート陽イオンが微量のク ロム酸イオンをともなって水溶液中からニトロベンゼン

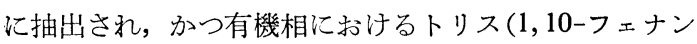
トロリン)鉄(II) キレートの吸光度が水相のクロム酸イ

* 金属キレート陽イオンを用いる陰イオンの溶媒抽出 (第 46 報). 前報法山本勇麓, 小林太郎, 日色和夫, 田中 孝: 衛生化学, 16, 114 (1970)

** 広島大学理学部化学教室：広島市東千田町
オンの濃度に比例することを見いだした・本報はこのよ うな現象に基ゔくクロムの新しい抽出吸光光度定量法の 基礎的条件を検討して最適の条件を確立したものであ る.さらにその有用性を確かめるために実試料として標 準鉄鋼試料を選えで分析し，良好な結果を得た。

\section{2 試薬および装置}

\section{1 試 薬}

（1）クロム (VI) 標準溶液：純品の重クロム酸カリ ウム（大阪工業技術試験所製標準試薬）を $120^{\circ} \mathrm{C}$ で約 1 時間乾燥後, その $0.7355 \mathrm{~g}$ をイオン交換水に溶かし て $250 \mathrm{ml}$ にうすめ, $1.00 \times 10^{-2} M$ の溶液を調製した。 実験に際してはイオン交換水でこれを正確に 100 倍にう すめてクロム（VI） $10.4 \mu \mathrm{g} / \mathrm{ml}$ として使用した。

(2) クロム (III) 標準溶液 : 特級硫酸クロム (III) カリウムの $9.989 \mathrm{~g}$ をイオン交換水に溶かし, $1 l$ にう すめて $1.00 \times 10^{-2} M$ のクロム (III) 溶液を調製した。 その正確な濃度はキレート滴定法6)によって標定した結 果, $1.00 \times 10^{-2} M$ であり, クロム (III) $1040 \mu \mathrm{g} / \mathrm{ml}$ 
に相当した。

(3) トリス $(1,10$-フェナントロリン)鉄(II) キレー 卜溶液：特級フェナントロリン（同仁薬化研製）の $6.938 \mathrm{~g}$ と特級硫酸鉄 $(\mathrm{II})$ フンモニウム（日本試真工業 製）の $3.922 \mathrm{~g}$ を少量の硫酸を含む水溶液に溶かした のち，イオン交換水で $1 l$ にうすめた。これはトリス

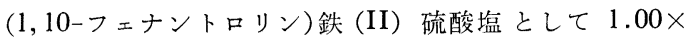
$10^{-2} M$ 溶液である.

(4) 放射性クロム-51 $\left(\mathrm{Na}_{2} \mathrm{CrO}_{4}\right)$ 溶液 : フランス CEA 社品を $0.01 N$ 硫酸で適当にうすめて使用した. 放射性クロムの放射化学的純度は半減期追跡により確認 した。

（5）緩衝溶液：酢酸と酢酸ナトリウムの各特級品 $1 M$ 溶液をつくり，それぞれを適当に混合して所定の $\mathrm{pH}$ に調整した.

(6) ニトロベンゼン：1 級品をあらかじめイオン交 換水と振り混ぜて平衡させたものを使用した。

（７）その他の試薬：すべて市販の特級品を使用し た。

\section{$2 \cdot 2$ 装}

吸光度測定には日立光電分光光度計 139 型を使用し, セルは光路長 $10 \mathrm{~mm}$ のガラスセルを用いた. $\mathrm{pH}$ の測 定には日立-堀場製 $\mathrm{H}-5$ 型 $\mathrm{pH}$ メーターを使用した. 振り混ぜ機はイワキ製の $\mathrm{KM}$ 式万能シェーカーを用い た. 放射能の測定には富士通製 GSC-500 型 GM 計数 装置を使用した。

\section{3 実験}

\section{1 標準操作}

クロム $(\mathrm{VI})$ 標準溶液 $(10.4 \mu \mathrm{g} / \mathrm{m} l) 5 \mathrm{ml}$, トリス $(1,10$-フェナントロリン)鉄 (II) キレート溶液 $10 \mathrm{ml}$ を分液漏斗 $(100 \mathrm{ml}$ 容量) に分取し, 酶酸塩緩衝溶液 $5 \mathrm{ml}$ を加えて $\mathrm{pH}$ を約 3.5 に調節し, イオン交換水 で全量を $25 \mathrm{ml}$ にうすめる. この溶液にニトロベンゼン $10.0 \mathrm{ml}$ を加え, 1 分間振り混ぜたのち, 分相のため約 30 分間静置する. 次に有機相を試験管に移し, 約 $1 \mathrm{~g}$ の無水硫酸ナトリウムを加えて脱水したのち，ニトロベ ンゼンまたは試薬ブランクを対照として $516 \mathrm{~m} \mu$ におけ る吸光度を測定する。

\section{2 吸収スペクトル}

操作 3.1 に従って得られた抽出相の吸収スペクトルを Fig. 1 に示す. 曲線 I はクロム (VI) を加えないとき (試薬ブランク), 曲線 II および III はクロム (VI) 標準溶液の $3 \mathrm{ml}$ および $5 \mathrm{ml}$ を採取したときの抽出相 のスペクトルである. Fig. 1 からクロム (VI) が存在し ない場合にはトリス $(1,10$ フェナントロリン)鉄(II) 陽 イオンはニトロベンゼン相に移行しないが，微量のクロ ム (VI) が存在するときはじめて抽出されることがわか

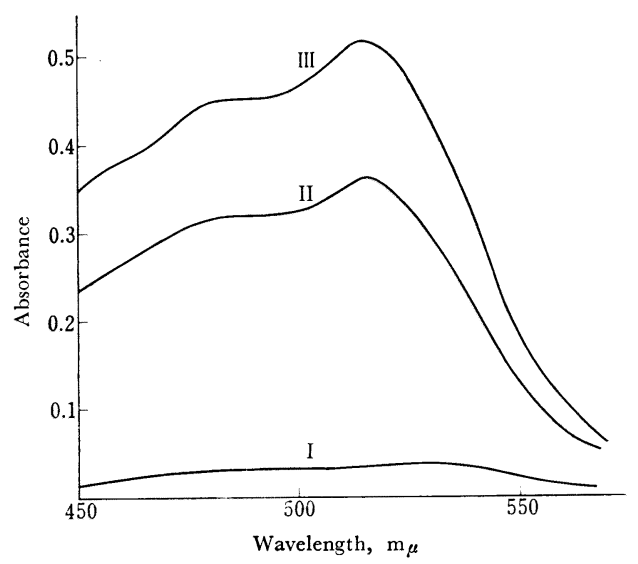

Fig. 1 Absorption spectra

Curve I : Reagent blank; Curve II : $\mathrm{Cr}(\mathrm{VI}) 3.2 \times$ $10^{-5} \mathrm{M}(1.66 \mu \mathrm{g} / \mathrm{ml}) ;$ Curve III : $\mathrm{Cr}(\mathrm{VI}) 4.8 \times 10^{-5} \mathrm{M}$ $(2.50 \mu \mathrm{g} / \mathrm{ml}) ; \mathrm{Fe}(\text { phen })_{3}{ }^{2+}: 4.0 \times 10^{-3} M$; Reference : Nitrobenzene

る. 水溶液におけるトリス $(1,10$-フェナントロリン)鉄 (II) キレートの吸収極大波長は $510 \mathrm{~m} \mu$ であるが，有 機相ではやや長波長へ移行して $516 \mathrm{~m} \mu$ に存在する。こ の深色効果は有機相におけるキレート陽イオンに対する 溶媒効果に基因するものと考えられる.

\section{3 pH の影響}

抽出に及ぼす $\mathrm{pH}$ の影響を検討するために操作 $3 \cdot 1$ において $\mathrm{pH}$ のみを変化させて抽出を行なった. その結 果は Fig. 2 に示すように, pH 3〜4 の範囲で吸光度は 最大であり，一定の抽出を示すことがわかる．このよう な $\mathrm{pH}$ 依存性は次式で示されるようなク口ム酸の水溶液 における解離平衡)が抽出に反映しているためと考えら れる。

$$
\begin{array}{lc}
\mathrm{H}_{2} \mathrm{CrO}_{4}+\mathrm{H}_{2} \mathrm{O} \rightleftarrows \mathrm{H}_{3} \mathrm{O}^{+}+\mathrm{HCrO}_{4}^{-} & \mathrm{p} K_{\mathrm{a}_{1}}=-0.7 \\
\mathrm{HCrO}_{4}-+\mathrm{H}_{2} \mathrm{O} \rightleftarrows \mathrm{H}_{3} \mathrm{O}^{+}+\mathrm{CrO}_{4}{ }^{2-} & \mathrm{p} K_{\mathrm{a}_{2}}=6.5 \\
\mathrm{Cr}_{2} \mathrm{O}_{7}{ }^{2-}+\mathrm{H}_{2} \mathrm{O} \rightleftarrows 2 \mathrm{HCrO}_{4}^{-} & \mathrm{p} K=1.5
\end{array}
$$

Hála $5^{8)}$ は上式から計算して $\mathrm{pH} 2 \sim 4$ の範囲に おいては，クロム（VI）のイオン種はほとえど 100\% $\mathrm{HCrO}_{4}$ - として存在しており $\mathrm{Cr}_{2} \mathrm{O}_{7}{ }^{2-}$ の存在は無視で きると述べている.したがって，この抽出系において抽 出される化学種恃 $\left[\mathrm{Fe}(\mathrm{phen})_{3}{ }^{2+}\right] \cdot\left[\mathrm{HCrO}_{4}{ }^{-}\right]_{2}$ と推定さ れる。

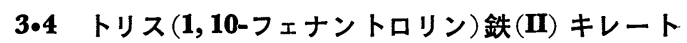

\section{陽イオン濃度の影響}

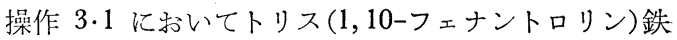




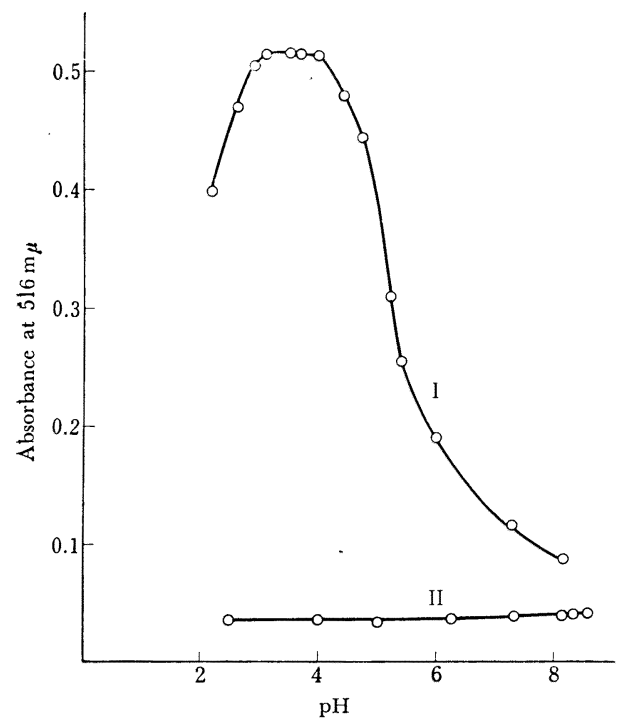

Fig. 2 Effect of $\mathrm{pH}$

Curve I : $\operatorname{Cr}(\mathrm{VI}) 2.5 \mu \mathrm{g} / \mathrm{m} l$; Curve II : Reagent blank; $\mathrm{Fe}(\mathrm{phen})_{3}{ }^{2+}: 4.0 \times 10^{-3} \mathrm{M} ; \quad$ Reference : Nitrobenzene

(II) キレート陽イオンの濃度を種々変化させて，金属 キレート陽イオン濃度が抽出に与える影響を検討した。 その結果を Fig. 3 に示す. キレート濃度がクロム (VI) の濃度に対してモル比で 50 倍以上であれ泟一定の吸光 度を示すようになる。したがって，本実験ではトリス (1,10-フェナントロリン)鉄(II) キレート陽イオン濃度

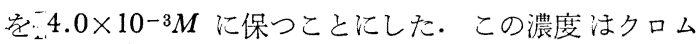
(VI) の 84 倍モルに相当する.

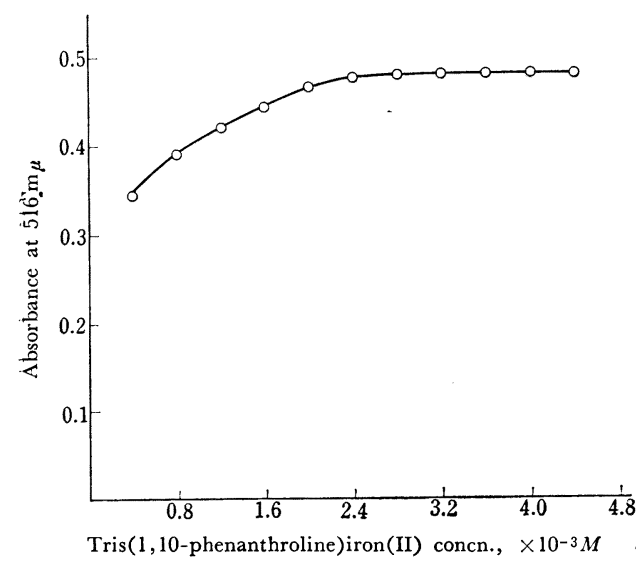

Fig. 3 Effect of chelate concentration $\mathrm{Cr}(\mathrm{VI}): 2.5 \mu \mathrm{g} / \mathrm{m} l ;$ Reference : Reagent blank; $\mathrm{pH}$ : 3.5

\section{5 抽出率}

放射性同位元素クロム-51 を含む一定濃度のクロム (VI) 溶液 $\left(4.00 \times 10^{-5} M\right)$ を調製し, 操作 3.1 によっ て得られた有機相と水相の $\gamma$ 線放射能を測定することに よって抽出率を求めた. その結果, 抽出率は $43.4 \pm$ 1.3\%（分配比=1.92）であった.

一方，トリス (1,10-フェナントロリン)鉄(II) キレー ト陽イオンが存在しないときのクロム (VI) の抽出挙動 については，3.3 において平衡式から考察したように重 クロム酸, クロム酸としてニトロベンゼンに抽出される 可能性はまず考えられないこのことを確からるため に，操作 3.1 に括いてトリス(1,10-フェナントロリン) 鉄 (II) キレート陽イオンを加えないで抽出した有機相 のクロム (VI) -51 の $\gamma$ 線放射能を測定した結果, 有機 相の放射能 はバックグラウンドとほとえど同じであっ た.すなわち，トリス(1,10ーフェナントロリン)鉄(II) キレート陽イオンが存在しなければクロム (VI) 法抽出 されないことが確認された。

\section{6 振り混ぜ時間の影響}

操作 3.1で振り混ぜ時間を種々变化させてその影響を 検討した. その結果，45 秒以上振り混ぜれば抽出平衡 に達することがわかった，したがって，本実験では便宜 上振り混ぜ時間を 1 分間とした。

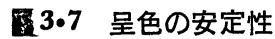

操作 3.1 に従って抽出した有機相に京ける吸光度の経 時变化を検討した結果, 抽出相の呈色は非常に安定で, 常温では 24 時間放置しても吸光度の变化はほとえど認 められなかった。

\section{8 溶媒の選択}

操作 $3 \cdot 1$ において二トロベンゼンのほかに，ベンゼ ン，クロルベンゼン，ブロムベンゼン，1,2-ジクロルエ タン, クロロホルム, 四塩化炭素, メチルイソブチルケ トン，酢酸ブチルおよび $n$-ブタノールなどの有機溶媒 について検討した．その結果，クロム(VI) が $2.5 \mu \mathrm{g} /$ $\mathrm{m} l$ 程度の濃度ではニトロベンゼン以外の溶媒では有機 相は呈色せず，したがってほとえど抽出されないことが わかった。 ニトロベンゼンがこのようなイオン対の抽出 に有効なのは，その誘電率が比較的大きいことが寄与し ていると考えられる。

\section{9 共存イオンの影響}

操作 $3 \cdot 1$ において種々の陰イオンおよび陽イオンが共 
存する場合について検討した。その結果を Table I お よび Table II に示す. Table I はクロム類縁元素の酸 素酸イオンおよび普通よく用いられる鉱酸の陰イオンの 場合である. Table I からわかるように，モリブデン， バナジウム，タングステン，マンガン，七素打よびセレ ンなどの酸素酸陰イオンは 5 倍モルまでは影響しない が，それ以上共存すると正誤差を与える。また，硝酸イ オン注 2 倍モル以上では正誤差を与えるが，塩素イオ ン，リン酸イオン，硫酸イオンおよび酶酸イオンなどは 多量共存してもさしつかえない. Table II に注通常の 鉄鋼中に存在すると考えられる金属イオン，および 1, 10-フェナントロリンと反応しやすい金属イオンの 許容 限度を示した。鉄（III)，鉛，ニッケルおよび銅 (II) は数倍モル，カドミウム，亜鉛およびコバルト（II）な ぞは 5 倍モル程度, マンガン (II) 注多量存在してもさ しつかえない。なお，クロム（III）は 100 倍モル共存 してもほとえぞ影響しない。

Table I Effect of diverse anions

\begin{tabular}{llc}
\hline \multicolumn{1}{c}{ Ion } & \multicolumn{1}{c}{ Added as } & $\begin{array}{c}\text { Permissible concentration } \\
\text { (mole ratio of ion to } \mathrm{Cr} \text { ) }\end{array}$ \\
\hline $\mathrm{Mo}_{2} \mathrm{O}_{7}{ }^{2-}$ & $\left(\mathrm{NH}_{4}\right)_{6} \mathrm{Mo}_{7} \mathrm{O}_{24} \cdot 4 \mathrm{H}_{2} \mathrm{O}$ & 5 \\
$\mathrm{WO}_{4}{ }^{2-}$ & $\mathrm{Na}_{2} \mathrm{WO}_{4} \cdot 2 \mathrm{H}_{2} \mathrm{O}$ & 3 \\
$\mathrm{VO}_{3}{ }^{-}$ & $\mathrm{NH}_{4} \mathrm{VO}_{3}$ & 5 \\
$\mathrm{MnO}_{4}{ }^{-}$ & $\mathrm{KMnO}_{4}$ & 3 \\
$\mathrm{AsO}_{3}{ }^{3-}$ & $\mathrm{Na}_{3} \mathrm{AsO}_{3}$ & 5 \\
$\mathrm{SeO}_{3}{ }^{2-}$ & $\mathrm{H}_{2} \mathrm{SeO}_{3}$ & 5 \\
$\mathrm{SO}_{4}{ }^{2-}$ & $\mathrm{K}_{2} \mathrm{SO}_{4}$ & 5 \\
$\mathrm{PO}_{4}{ }^{3-}$ & $\mathrm{KH}_{2} \mathrm{PO}_{4}$ & 1000 \\
$\mathrm{Cl}^{-}$ & $\mathrm{KCl}$ & 1000 \\
$\mathrm{NO}_{3}{ }^{-}$ & $\mathrm{KNO}_{3}$ & 200 \\
\hline
\end{tabular}

$\operatorname{Cr}(\mathrm{VI}): 1.66 \mu \mathrm{g} / \mathrm{ml}\left(3.2 \times 10^{-5} \mathrm{M}\right) ;$ Permissible error : $\pm 3 \%$

Table II Effect of diverse cations

\begin{tabular}{clc}
\hline Ion & \multicolumn{1}{c}{ Added as } & $\begin{array}{c}\text { Permissible concentration } \\
\text { (mole ratio of ion to } \mathrm{Cr} \text { ) }\end{array}$ \\
\hline $\mathrm{Cr}^{3+}$ & $\mathrm{K}_{2} \mathrm{Cr}_{2}\left(\mathrm{SO}_{4}\right)_{4} \cdot 24 \mathrm{H}_{2} \mathrm{O}$ & 100 \\
$\mathrm{Mn}^{2+}$ & $\mathrm{MnSO}_{4} \cdot 7 \mathrm{H}_{2} \mathrm{O}$ & 40 \\
$\mathrm{Fe}^{3+}$ & $\mathrm{Fe}_{2}\left(\mathrm{SO}_{4}\right)_{3} \cdot 7 \mathrm{H}_{2} \mathrm{O}$ & 3 \\
$\mathrm{Co}^{2+}$ & $\mathrm{CoSO}_{4} \cdot 7 \mathrm{H}_{2} \mathrm{O}$ & 8 \\
$\mathrm{Ni}^{2+}$ & $\mathrm{NiSO}_{4} \cdot 7 \mathrm{H}_{2} \mathrm{O}$ & 5 \\
$\mathrm{Cu}^{2+}$ & $\mathrm{CuSO}_{4} \cdot 5 \mathrm{H}_{2} \mathrm{O}$ & 5 \\
$\mathrm{Zn}^{2+}$ & $\mathrm{ZnSO}_{4} \cdot 7 \mathrm{H}_{2} \mathrm{O}$ & 5 \\
$\mathrm{Cd}^{2+}$ & $\mathrm{CdSO}_{4} \cdot 2 \frac{2}{3} \mathrm{H}_{2} \mathrm{O}$ & 5 \\
$\mathrm{~Pb}^{2+}$ & $\mathrm{Pb}^{2+}\left(\mathrm{CH}_{3} \mathrm{COO}_{2} \cdot 3 \mathrm{H}_{2} \mathrm{O}\right.$ & 2 \\
\hline $\mathrm{Cr}(\mathrm{VI}): 1.66 \mu \mathrm{g} / \mathrm{ml}\left(3.2 \times 10^{-5} M\right) ; \quad$ Permissible error $: \pm 3 \%$
\end{tabular}

\subsection{0 検量線 (I)}

操作 $3 \cdot 1$ においてクロム (VI) の添加量を変化させ て検量線を作成した．その結果を Fig. 4 の直線（I）に

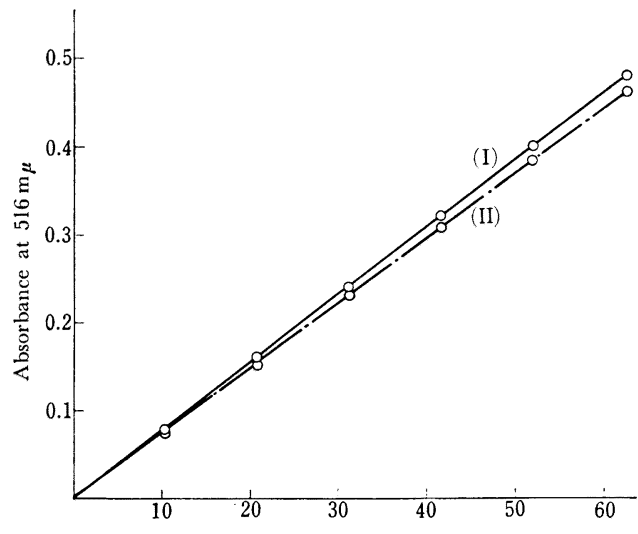

Chromium $\mu \mathrm{g}$ in $25 \mathrm{ml}$ of aqueous phase

Fig. 4 Calibration curves

Curve(I) : Obtained from $\mathrm{Cr}(\mathrm{VI})$ solution; Curve (II) : Obtained from $\mathrm{Cr}$ (III) solution after oxidation with hydrogen peroxide; $\mathrm{Fe}(\text { phen })_{3}{ }^{2+}: 4.0 \times$ $10^{-3} \mathrm{M}$; Reference : Reagent blank; $\mathrm{pH}: 3.5$

示す.クロム濃度が $62.5 \mu \mathrm{g} / 25 \mathrm{ml}$ 以下の範囲で直線 関係が得られた。次にクロム（VI）の濃度を $2.08 \mu \mathrm{g} /$ $\mathrm{m} l$ に保って 11 回のくりかえし精度を求めた結果は平 均吸光度の 0.4001 に対して $0.52 \%$ であり，本法の精 度はきわめて良好であることを示している．抽出時にお ける温度の影響を検討した結果, $10 \sim 25^{\circ} \mathrm{C}$ の範囲内で は吸光度に注々えど变化が認められなかった。しか し，それ以上の高温で法わずかながら吸光度が減少する 傾向を示した。

\section{4 実試料への忘用：鉄鋼の分析}

以上のような基礎的条件を種々検討した結果, 本法に よって微量のクロムを精度よく定量できることがわかっ たので，実試料への応用の試みとして標準鉄鋼試料につ いてクロムの定量を行なった。

\section{1 検量線 (II)}

実試料を分析するにあたって後述のように種々検討し た結果，多量の鉄共存下に抢沙るクロムの検量線の作成 条件を次のように定めた。

電解鉄の約 $0.2 \mathrm{~g}$ を正確にはかりとり, $300 \mathrm{ml}$ 容量 のビーカーに移す.これに塩酸 $(2: 1)$ の $50 \mathrm{ml}$ を加え て加熱溶解する. ついで硝酸の 2 3 $\mathrm{ml}$ を加壳てほとえ ぞ乾固するまで加熱蒸発させる. 冷却後, 塩酸 $(1: 1)$ で溶解し， $100 \mathrm{~m} l$ のメスフラスコに洗い移したのち, この塩酸で標線までうすめる. この溶液の $10 \mathrm{ml}$ を 25 $\mathrm{m} l$ のメスフラスコにとり，ついでクロム(III) 標準溶 
液 $(10.4 \mu \mathrm{g} / \mathrm{ml}, 6 N$ 塩酸溶液 $)$ の $0 \sim 6 \mathrm{ml}$ を加えた のち，塩酸 $(1: 1)$ で定容する.

この溶液を分液漏斗に移し，これに MIBK-iso-酢酸 アミル (1:1) 混合溶媒の $25 \mathrm{~m} l$ 加え, 5 分間振り混ぜ て鉄を抽出除去する. 約 30 分間静置したのち，分離す る. 水相にふたたび新しい MIBK-iso-酢酸アミル（1： 1) の $25 \mathrm{ml}$ を加えて, 同様に抽出する. 水相を $200 \mathrm{ml}$ 容量のビーカーに移し, 硫酸 (1:1) の $3 \mathrm{ml}$ を加え, 加熱白煙処理して 過剩の塩酸を除去する. 冷却後， $6 \%$ 過酸化水素水の $1 \mathrm{ml}, 4 N$ 水酸化ナトリウムの $20 \mathrm{ml}$ を加えてアルカリ性にし，加熱してクロム(III) をクロ ム (VI) に酸化する. さらに加熱を続けて過酸化水素を じゅうぶんに分解除去する. 冷却したのち, 硫酸 (1:5) を用いて $\mathrm{pH}$ 3〜 4 に調節し， $50 \mathrm{ml}$ のメスフラス コに移してイオン交換水で定容する. この溶液の $10 \mathrm{ml}$ を $100 \mathrm{ml}$ 分液漏斗に分取し, 以後操作 3.1 に従って 検量線を作成する.

結果を Fig. 4 の直線（II）に示すが，クロム (VI) の標準溶液から作成した検量線 Fig. 4 の直線 (I) に比 ベるとわずかに低い傾斜を示している。これはクロム (III) からクロム（VI）への酸化がやや不完全なためと 考えられるが詳細については 4.4 で述べる。

実試料を分析する場合は試料約 $0.2 \mathrm{~g}$ を正確にはか りとり, 溶解および抽出操作はまったく上記の操作に従 い, 検量線 (II) からクロム量を求める.

\section{2 試料の溶解}

JIS 法9)では普通の炭素鋼のクロムを分析する場合， 混酸（リン酸：硫酸：硝酸：水 $=3: 4: 1: 22$ ) を用い て試料を溶解するように指定されているが，試料 GK15 のようにニッケル量が比較的高い鋼に対しては王水 を用いるほうがよいとされている. 試料の溶解法として 王水を用いた場合と，混酸で分解した場合とを比較検討 したが両者に大きな差異はみられなかった．さらに本法 では多量の鉄が妨害するので（Table II），後述のよう に塩酸酸性での溶媒抽出で鉄を除去する必要がある。以 上の観点から王水溶解法を採用することにした。なお， 念のために試料 GK-15に対しては王水と混酸の両者を 比較検討したが，クロムの定量值には差異は認められな かった。

\section{3 鉄の除去の検討}

既述のように多量の鉄 (III) が本抽出系では妨害する のでその対策を検討する必要がある・まずフッ素イオ ン, リン酸イオン, クエン酸, 酒石酸あるいは EDTA
などで多量の鉄をマスクする方法が考えられるが，ここ では溶媒抽出による鉄の除去法を種々検討した. 多量の 鉄を抽出する方法としてはアセチルアセトン，クペロン およびオキシンなどを用いる方法 ${ }^{10)}$ ，塩酸酸性でエチル エーテルおよび iso-プロピルエーテルなどによる方法 ${ }^{10)}$ が知られている. 特に MIBK 抽出系については後藤

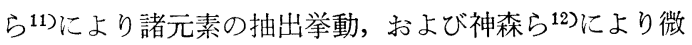
量不純物の抽出挙動が放射性同位元素を用いて精細に検 討されている. その結果によれば，クロム(III) は塩酸 酸性ではまったく抽出されないが，クロム(VI) はよく

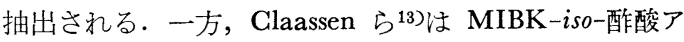
ミル混合溶媒を用いると鉄の分配比も高く, MIBK 単 独の場合よりも分相が容易であると報告している、いず れにしてもクロム (III) が抽出されないことを確かめて おく必要があるので，著者らもクロム（VI）-51 をク口 ム (III) -51 に還元し，これをトレーサーとして多量の 鉄共存下での MIBK と MIBK-iso-酢酸アミル混合溶 媒による抽出挙動の差異を比較検討した。そ結果，ク ロム (III) の抽出率汇 MIBK の場合 $1.09 \pm 0.20 \%$, MIBK-iso-酶酸アミルの場合は $1.00 \pm 0.19 \%$ であり， いずれもクロム (III) はほとんど抽出されないことが確 認された。 そこで本実験では MIBK-iso-酢酸アミル混 合溶媒を用いることにした。

\section{4 クロムの酸化剈の検討}

クロム（III）をクロム（VI）に酸化する場合，JIS 法9)では過硫酸アンモニウムや過マンガン酸カリウムが 用いられている.しかし過硫酸および過マンガン酸イオ ンはトリス (1,10-フェナントロリン)鉄(II) とともに抽 出されることがわかった. さらに過剩の過マンガン酸イ オンを尿素-覀硝酸ナトリウムで分解することも試みた が，このときの分解生成物がトリス $(1,10$-フェナントロ リン)鉄(II) とともにニトロベンゼンに抽出されるため にブランク值もかなり高くなり，乙かもばらつきも大き いことが認められた。次に，過酸化水素水を加えたの ち，水酸化ナトリウム溶液を加えアルカリ性で酸化する 方法を検討した. 操作 4.1 において過酸化水素水の添加 量を变化させてクロムを抽出定量した結果，6\% 過酸化 水素水の $0.5 \mathrm{ml}$ 以上ではクロムの回収率が一定となり 96.6\% であった。 寸なわち，過酸化水素水を酸化剤と して用いた場合には，クロム(III) からクロム (VI) への酸化がやや不完全であることを示し，Fig. 4 の直線 （II）の傾きが直線（I）の約 96\% であることに対応し ている. 


\section{5 酸化過程における共存イオンの影響}

クロム (III) からクロム (VI) への酸化過程におい テニッケル，銅 (II) およびマンガン (II) の影響を検 討した. その結果を Fig. 5 に示す.ニッケル (II) はク ロムに対して 2 倍モル, 銅（II）は 4 倍モルおよびマン ガン（II） は8倍モルまで共存しても影響しないが，そ れ以上では負の誤差を与えるようになる。

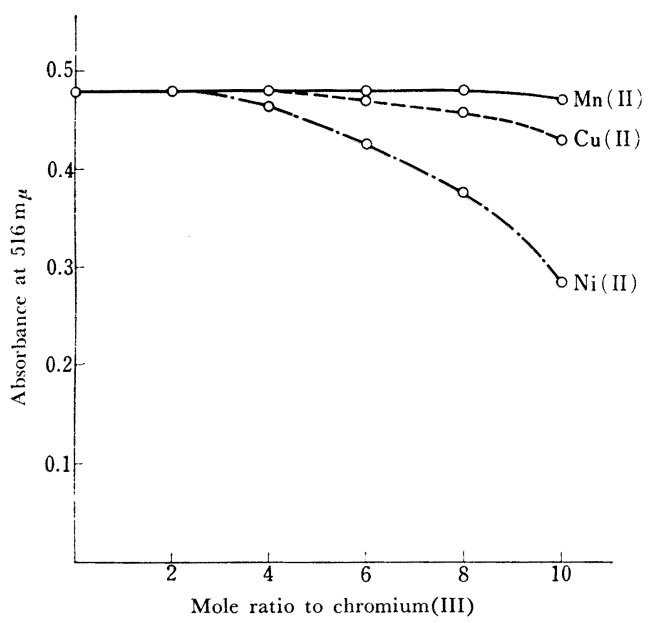

Fig. 5 Effect of $\mathrm{Mn}, \mathrm{Cu}$, and $\mathrm{Ni}$ on oxidation of $\mathrm{Cr}$ with hydrogen peroxide $\mathrm{Cr}(\mathrm{III}): 2.5 \mu \mathrm{g} / \mathrm{ml} ; \quad \mathrm{Fe}(\text { phen })_{3}{ }^{2+}: 4.0 \times 10^{-3} \mathrm{M}$; Reference : Reagent blank; $\mathrm{pH}: 3.5$

\section{6 分析結果}

操作 4.1 に従って, 標準鉄鋼試料 [GK-15(Ni-Cr$\mathrm{Mo}-\mathrm{V}$ 鋼) および GK-18 ( $\mathrm{Cr}-\mathrm{Mo}$ 鋼)] 中のクロムを 定量した結果を Table III に示す. Table III からわ ふるように JIS 法による定量結果とよく一致している.

Table III Determination of chromium in standard iron steel samples

\begin{tabular}{ccc}
\hline Sample & $\begin{array}{c}\text { Standard } \\
\text { value }\end{array}$ & $\begin{array}{c}\text { Found by } \\
\text { proposed method }\end{array}$ \\
\hline GK-15 & $1.001 \pm 0.023$ & $1.02_{4}$ \\
& $1.00_{3}$ \\
& & $1.01_{2}$ \\
& & $0.99_{8}$ \\
GK-18 & $1.00_{4}$ \\
& $2.175 \pm 0.028$ & $2.19_{5}$ \\
& $2.16_{7}$ \\
& $2.17_{9}$ \\
\hline
\end{tabular}

\section{5 結 $\quad \overrightarrow{\overline{\bar{े}}}$}

クロムの新しい抽出吸光光度法を提案した．本法はク

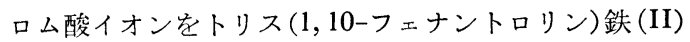
キレート陽イオンとともにニトロベンゼンに抽出し, 有 機相の赤色強度を測定することによってクロムを定量す るものである.クロムが試料中でクロム (VI) として存 在する場合にはとのまま適用できるが，クロム(III)の 場合には酸化する必要があり，アルカリ性における過酸 化水素水による酸化法が適切であることがわかった。

本法の感度は Sandell の表わし方で示すと $0.005 \mu \mathrm{g}$ $\mathrm{Cr} / \mathrm{cm}^{2}$ であり, ジェニルカルバジド法の感度 0.002 $\mu \mathrm{g} \mathrm{Cr} / \mathrm{cm}^{2}$ 1) に比べると低いが，精度がきわめて良好 である.鉄鋼試料に適用する場合，多量の鉄を除去すれ ば良好な結果が得られた. 本法は鉄などの共存が比較的 少ない他の試料に対してもじゅうぶえ適用されうるもの と考えら机る.

\section{(昭和 43 年 4 月, 日本化学会) 第 21 年会において一部講演) \\ 交 献}

1) E. B. Sandell : "Colorimetric Determination of Traces of Metals", 3rd Ed., p. 392 (1959), (Interscience Publishers, Inc., New York).

2) E. I. Savichev, E. I. Iskhakova, L. F. Flyazhnikova : Zavodsk. Lab., 28, 412 (1962).

3) R. Bock, C. Hummel : Z. Anal. Chem., 198, 196 (1963).

4) R. Bock, J. Jainz : ibid., 198, 315 (1963).

5) 後藤秀弘，小林純一：日化，75，964 (1954).

6)上野景平：“キレート滴定法”， p. 247(1964), (南江堂).

7) J. R. Neuss, K. Rieman : J. Am. Chem. Soc., 56, 2238 (1934).

8) J. Hâla, O. Navrátil, V. Nechuta : J. Inorg . Nucl. Chem., 28, 553 (1966).

9) JIS G 1217 (1963).

10) G. H. Morrison, H. Freiser : "Solvent Extraction in Analytical Chemistry", (1957), (John Wiley \& Sons Inc., New York).

11) 後藤秀弘, 柿田八千代, 古川 洸：日化， 79, 1513 (1958).

12) 神森大彦, 䯩張友夫, 坂東昭次 : 本茫， 16, 826 (1967).

13) A. Claassen, L. Bastings : Z. Anal. Chem., 160, 403 (1958).

Spectrophotometric determination of chromium(VI) by solvent extraction with tris $(1,10-$ phenanthroline)iron $(\mathbf{I I})$ chelate cation. (The spectrophotometric determination of anions by solvent extraction with metal chelate cations. XLVI.) Yuroku Yamamoto, Takahiro Kumamaru, Yasuhisa Hayashi, Shigekazu Kimura and Kiyoshi FuKami (Department of Chemistry, Faculty of Science, Hiroshima University, Higashisenda-machi, Hiroshima-shi) 
A new spectrophotometric determination of chromium(VI) based on solvent extraction has been developed. A small amount of chromium(VI) was found to be selectively extracted into nitrobenzene when a considerable amount of tris(1, 10-phenanthroline)iron(II) chelate cation was present in an aqueous medium. Constant extractability was observed over the $\mathrm{pH}$ range of $3 \sim 4$, provided the metal chelate concentration was 50 -fold molar excess over chromium(VI). The absorbance at $\lambda_{\max }(516 \mathrm{~m} \mu)$ of the extract was found to be proportional to the chromium(VI) concentration ranging from $10 \sim 62.5$ $\mu \mathrm{g} / 25 \mathrm{ml}$ initially present in the aqueous phase. The extracted species was assumed to be $\left[\mathrm{Fe}(\text { phen })_{3}{ }^{2+}\right]$. $\left[\mathrm{HCrO}_{4}^{-}\right]_{2}$ from the equilibrium constant of the chromate ion in slightly acidic medium. The absorbance of the extract was almost unchanged for 24 hours after the extraction. The standard deviation was $0.52 \%$ with a mean absorbance of $0.4001(2.08$ $\mu \mathrm{g} / \mathrm{m} l$ in chromium concentration, 11 samples). A large amount of iron(III) caused a considerable negative error and it was removed by solvent extraction with a methylisobutyl ketone-isoamyl acetate mixture. The developed method was applied to analysis of steel for chromium with satisfactory results.

(Received Jan. 10, 1970)

\title{
昇温ガスクロマトグラフィーの相対保持値と等温 ガスクロマトグラフィーの相対保持值との関係
}

\author{
竹 村 功* \\ (1970 年 1 月 19 日受理)
}

\begin{abstract}
昇温ガスクロマトグラフィーの相対保持值と，等温ガスクロマトグラフィーの相対保持值の対数との 間沉，同一操作条件下では同族列だけでなく異族間にも同じ一次関係がなりたった。この一次関係の こう配は Giddings の式との組み合わせによれば，次の六つの因子に影響されることが推測された。(1) 等温ガスクロマトグラフィーにおけるカラム温度 $(T)$, (2) 内部標準物質 $\left(A H_{\mathrm{VS}}\right)$, (3) 初期温度 $\left(T_{0}\right)$, (4) 昇温速度 $(r)$, (5) キャリヤーガス流量 $(F)$, (6) カラム長さ.

(3)，(4)の因子については，経験的ではあるが既報においてこう配に影響を与える因子であることを知 った。本報ではおもに(1)，(2)，(4)，(5)について，理論式と実験結果とを比較検討した。実験の結果は， こう配は $1 / T, \Delta H_{\mathrm{VS}} ， r$ ，そして $1 / F$ に関してそれぞれ一次関係があった。
\end{abstract}

\section{1 序論}

昇温ガスクロマトグラフィー（PTGC）の有用性注い まさらいうまでもないが，その広範な適用はいまだに妨 菭られてる。それは，定性分析するについても同一条 件下でそれ汇必要な基礎データをまず集めなければなら ないからた，再現性にまだ不安のあるPTGC では，こ とに未知物質の検索の場合に困難が伴ってくる.

著者は，PTGC でのこうした繁雑さを軽減するため に，再現性がよく今日まで豊富なまでに整理された等温 ガスクロマトグラフィー（IGG）のデータをPTGC 適用することを試みたところ，同一条件下であるならば

*マックスファクター株式会社：東京都品川区西五反 田 8 丁目
同族列だけでなく異族間にも，IGC の相対保持值 $\left(R_{\mathrm{IT}}\right)$ の対数と PTGG の相対保持值 $\left(R_{\mathrm{PT}}\right)$ との間に次の亡 うな一つの一次関係があることを知った1).

$$
\log R_{\mathrm{IT}}=m\left(R_{\mathrm{PT}}-1\right)
$$

こう配 $m$ は, 経験的ではあるが, 昇温速度や初期温度 などの実験条件によって変動することがわかっている。 しかしながら，あらかじめ数種の物質についた（1）式 の関係を求めて打けば， $R_{\mathrm{IT}}$ から $R_{\mathrm{PT}}$ 足予測するこ之 ができ，PTGCでの繁雑な予備実験を省略することぶ できた。

本報は，こう配 $m$ がいかなる因子に依存するものなの かを考察するものである。 